\title{
HFE Gene
}

National Cancer Institute

\section{Source}

National Cancer Institute. HFE Gene. NCI Thesaurus. Code C124875.

This gene plays a role in the modulation of iron transport. 